\title{
Response of black gram varieties to sowing times under rain fed vertisol of Southern Tamil Nadu
}

\author{
S. Subbulakshmi \\ Agricultural Research Station (T.N.A.U.), Kovilpatti (T.N.) India \\ (Email: subbuagri@ rediffmail.com)
}

\begin{abstract}
The field experiments were conducted during 2010-11, 2011-12 and 2012-13 in Rabi season (October - December) at Agricultural Research station, Kovilpatti to identify the optimum time of sowing and best suitable blackgram variety for rainfed vertisol. Experiments were laid out in split-plot design with three replications. The treatment combinations comprised of three dates of sowing viz., $39^{\text {th }}, 41^{\text {st }}$ and $43^{\text {rd }}$ standard weeks (pre monsoon, monsoon and post monsoon sowing, respectively) in main plot with four different black gram varieties viz., $\mathrm{CO} 5, \mathrm{CO}$ 6, Vamban 4 and Vamban 5 in the sub plot. The results revealed that sowing during $39^{\text {th }}$ standard week (pre monsoon- $\mathrm{D}_{1}$ ) registered increased growth and yield parameters viz., plant height, DMP,LAI, number of pods/plant, number of seeds/pod, pod length, 100 seed weight, which reflected on increased grain yield. Similarly among the varieties tried CO 5 registered higher growth and yield attributes which reflected on increased grain yield which was followed by Vamban 4.
\end{abstract}

Key Words : Black gram, Dates of sowing, Genotypes, Growth, Yield

View Point Article : Subbulakshmi, S. (2019). Response of black gram varieties to sowing times under rain fed vertisol of Southern Tamil Nadu. Internat. J. agric. Sci., 15 (1) : 190-194, DOI:10.15740/HAS/IJAS/15.1/190-194. Copyright@ 2019: Hind Agri-Horticultural Society.

Article History : Received : 15.10.2018; Revised : 21.12.2018; Accepted : 27.12.2018 